\title{
Handbook of Florida Water Regulation: Consumptive Use ${ }^{1}$
}

\author{
Michael T. Olexa, Luke D'Isernia, Laura Minton, Dulcy Miller, and Sarah Corbett ${ }^{2}$
}

\section{Preface}

This handbook is designed to provide an accurate, current, and authoritative summary of the principle Federal and Florida laws that directly or indirectly relate to agriculture. This handbook should provide a basic overview of the many rights and responsibilities that farmers and farmland owners have under both Federal and Florida laws as well as the appropriate contact information to obtain more detailed information. However, the reader should be aware that because the laws, administrative rulings, and court decisions on which this handbook is based are subject to constant revision, portions of this publication could become outdated at anytime. Several details of cited laws are also left out due to space limitations.

This handbook is distributed with the understanding that the authors are not engaged in rendering legal or other professional advice, and the information contained herein should not be regarded as a substitute for professional advice. This handbook is not all inclusive in providing information to achieve compliance with the Federal and Florida laws and regulations governing water protection. For these reasons, the use of these materials by any person constitutes an agreement to hold harmless the authors, the Florida Cooperative Extension Service, the Institute of Food and Agricultural Sciences, and the University of Florida for any liability claims, damages, or expenses that may be incurred by any person as a result of reference to or reliance on the information contained in this handbook.

\section{Who Regulates Consumptive Use?}

Both the water management districts' (WMD) governing boards, which are charged with maintaining the state's reserves of usable water at an acceptable level, and the Florida Department of Environmental Protection (DEP) are vested with the authority to require consumptive use permits and impose conditions upon those permits. This is in accordance with Florida's water use policy, which gives preference to desirable uses and thus promotes natural resource, fish, and wildlife preservation. This authority is delegated almost entirely to the WMDs,

1. This is EDIS document FE604, a publication of the Food and Resource Economics Department, Florida Cooperative Extension Service, Institute of Food and Agricultural Sciences, University of Florida, Gainesville, FL. Published December 2005. Please visit the EDIS website at http://edis.ifas.ufl.edu.

2. Michael T. Olexa, Professor, Food and Resource Economics Department, Florida Cooperative Extension Service, Institute of Food and Agricultural Sciences, University of Florida, Gainesville, FL; Director, Agricultural Law Center, University of Florida, Gainesville, FL; and Chair, Agricultural Law Committee of The Florida Bar. Luke D'Isernia, former student (graduated cum laude in 2005), Levin College of Law, University of Florida, Gainesville, FL. Laura Minton, Attorney, Dean, Mead, Egerton, Bloodworth, Capouano, and Bozarth, Orlando, FL. Dulcy Miller, attorney, Foley and Lardner, LLP, Orlando, FL. Sarah Corbett, Attorney, Florida Second District Court of Appeal, Lakeland, FL. 
which should be consulted before any consumptive use of water is undertaken.

\section{What Permits Are Required?}

When a party's water usage reaches any of certain pre-determined threshold levels, the WMD will require a permit. Threshold levels are determined by the individual WMDs; it is important to consult the appropriate WMD regarding this threshold. Two types of permits, individual and general, are relevant to water consumption as follows:

1. Individual permits are required when withdrawal exceeds established daily limits that are measured in gallons per day.

2. General permits apply where the amount of the withdrawal will be minimal as set forth in the various WMDs' rules.

All uses must be permitted unless exempted, including existing uses. This means there are no special exemptions for withdrawals from ground or surface waters which were in existence before the consumptive permitting requirements became effective.

Exemptions generally include the following:

- Individual residential consumption.

-Wells for testing or monitoring water quality.

- Private, shallow wells.

- Certain heating and cooling systems.

- Dewatering activities necessary for construction, if they are completed in less than six months.

The statutory exemption, however, does not absolve farmers who are making residential use of water from observing common law duties (see FE598, Private Regulation, for examples). Generally, this means that the use of the water supply must be reasonable. Several factors may be used by the courts to determine the "reasonableness" of the use, including:
- The purpose of the use.

- The suitability of the body of water.

- The relative economic and social values.

- The degree of harm to the environment.

- The practicality of avoiding the harm or the practicality of adjusting the quantity of the usage.

\section{What Kind of Water Is Permitted?}

For the most part, the water permitted for consumptive use is groundwater. However, the Florida Legislature has recently found that the use of reclaimed water provided by domestic wastewater treatment plants is safe. So, in an effort to promote and encourage water conservation, WMDs now permit the use of reclaimed water. Contact the local WMD to find out more about this new source for consumptive use.

\section{What Are the Effects of Permits?}

Permits are only granted for fixed periods of time. Except for public facilities, they may not exceed twenty years and are usually granted for much shorter periods. When the nature of a proposed use is such that the permit application process may be lengthy, the WMD may issue a temporary permit. Transfer of permits between activities identical in nature at the same location is usually allowed and conditions of the permit usually remain the same. There are different requirements for Individual and General Water permits.

\section{When Is a Permit Revoked?}

Any failure to continually observe the terms provided by a permit may result in its revocation. Other grounds for revocation may include nonuse of the permitted area or facility or unsatisfactory mitigation (reduction or lessening) of environmental damage from the use.

\section{Source}

Chapter 373, Florida Statutes, Sections 373.203 to 373.250; Title 40, Florida Administrative Code (individual WMD rules) 


\title{
Contact Information
}

\author{
Consumptive Use (FE616, Contact Agencies)
}

- S-1, Florida Water Management Districts

\section{Acknowledgments}

The authors are indebted to the personnel of both state and federal agencies who provided their time and advice in the preparation of this handbook. The authors are especially indebted to Richard Budell of the Office of Agricultural Water Policy of the Florida Department of Agriculture and Consumer Services for providing funds for the development of this publication. 